\title{
Optimizing content of Pyrovatex CP New and Knittex FFRC in flame retardant treatment for cotton fabric
}

\author{
DOI: 10.35530/IT.072.03.1648
}

NGUYEN PHAM DUY LINH

Optimizing content of Pyrovatex CP New and Knittex FFRC in flame retardant treatment for cotton fabric

In this study, the flame-retardant treatment for cotton fabric has been done by using the commercial organophosphorus compounds labelled Pyrovatex CP New (PR). Knittex FFRC (K), a formaldehyde-free crosslinking agent, has been used to enhance the link between Pyrovatex CP New and Cellulose molecules. The flame-retardant treatment process for cotton fabric has been done by the pad-dry-cure technique. The purpose of the study is to predict the optimal Pyrovatex CP New and Knittex FFRC concentrations with the highest fire resistance efficiency, minimum loss for mechanical properties and minimum formaldehyde release for the treated fabric. To achieve this goal, the response surface methodology (RSM) was used to find the relationship between the controlled experimental factors and the observed results. The central composite design type face centred (CCF) was applied as experimental design. According to this experimental design, 10 experiments were carried out. The chemical uptake rate, vertical flammability characteristics, $\mathrm{LOI}$ value, tensile strength and formaldehyde-free content of the untreated and treated samples were determined. Four response models between the reagent concentrations and the add-on amount, LOI value, warp and weft tensile strength of the treated fabric were obtained by the assistance of software Design-Expert $V 10.0 .8$. The R-squared values of these models were above $80 \%$ confirming their significances. The optimal conditions when combining three parameters (LOI, warp tensile strength and weft tensile strength) were selected as $450 \mathrm{~g} / \mathrm{l}$ Pyrovatex CP New and 107,575 g/l Knittex FFRC with the assistance of Design-Expert software.

Keywords: cotton, Pyrovatex CP New, Knittex FFRC, durable flame retardant, response surface methodology, central composite designs

\section{Optimizarea conținutului de Pyrovatex CP New și Knittex FFRC în tratamentul de ignifugare al țesăturii din bumbac}

În acest studiu, tratamentul de ignifugare al țesăturilor din bumbac a fost realizat prin utilizarea compușilor organofosforici comerciali Pyrovatex CP New (PR). Knittex FFRC (K), un agent de reticulare fără formaldehidă, a fost utilizat pentru a îmbunătăți legătura dintre moleculele de Pyrovatex CP New și cele de celuloză. Procesul de tratare ignifugă a țesăturii din bumbac a fost realizat prin tehnica de fulardare-uscare-condensare. Scopul studiului este de a identifica concentrațiile optime de Pyrovatex CP New și Knittex FFRC, cu cea mai mare eficiență de rezistență la foc, pierderi minime pentru proprietățile mecanice și eliberare minimă de formaldehidă pentru țesătura tratată. Pentru a atinge acest obiectiv, metodologia suprafeței de răspuns (RSM) a fost utilizată pentru a găsi relația dintre factorii experimentali controlați și rezultatele observate. Tipul de proiectare a compozitului central (CCF) a fost aplicat în proiectarea experimentală. Conform acestui plan experimental, au fost efectuate 10 experimente. S-au determinat rata de absorbție chimică, caracteristicile de inflamabilitate verticală, valoarea LOI, rezistența la tracțiune și conținutul de formaldehidă din probele netratate și tratate. Patru modele de răspuns între concentrațiile de reactiv și cantitatea suplimentară, valoarea LOI, rezistența firelor de urzeală și de bătătură ale țesăturii tratate au fost obținute cu ajutorul software-ului Design-Expert $V$ 10.0.8. Valorile pătratice $R$ ale acestor modele au fost de peste $80 \%$, confirmându-le semnificația. Condițiile optime la combinarea a trei parametri (LOI, rezistență firelor de urzeală și de bătătură) au fost selectate cantitățile 450 g/l Pyrovatex CP New și 107.575 g/l Knittex FFRC, cu ajutorul software-ului Design-Expert.

Cuvinte-cheie: bumbac, Pyrovatex CP New, Knittex FFRC, ignifugare durabilă, metodologie de suprafață de răspuns, modele compozite centrale

\section{INTRODUCTION}

Cotton is one of the most abundantly used fibres. But it is one of the most flammable fibres as well with low limiting oxygen index (LOI) of $18.4 \%$ and onset of pyrolysis at $350^{\circ} \mathrm{C}$ [1]. Therefore, cotton is burn with hot flames and light smoke [2,3]. Hence, the application of flame-retardant (FR) products on cotton is an important textile issue.
Durable flame-retardant cotton fabric is required in many uses such as home textiles; uniforms for firefighters; apparels and garments. Among the durable flame retardants, phosphorus-based flame retardants have been a major source of interest because of their environmentally friendly products and their low toxicity [4]. Durable flame-retardant finishes of cotton using phosphorus-based flame retardants are classified 
into two types depending on the way of the covalently bond flame retardant reacts to cellulose. One is the reactive finish that reacts with cellulose hydroxyl groups and forms covalent bond. These are mainly based on $\mathrm{N}$-methylol dimethyl phosphonopropion amide (MDPA). The other is non-reactive finish that forms insoluble crosslinked polymer network inside the cellulose fiber. However, it requires the complex application method due to the use of special ammonia chamber and it is not compatible with sulphur dyes [5]. While the reactive finish based on MDPA is also durable, and the application method is simple. Therefore, MDPA-based FRs have been used until present days.

MDPA has methyl group which reacts with cellulose. Furthermore, crosslinking agents are used to improve the durability of the finish and to improve the phosphorus nitrogen synergistic effect [5-8]. MDPA with the trade names of "Pyrovatex CP" or "Pyrovatex CP New" have been the most useful approach to obtain durable flame-retardant finishes for cotton $[2,6,9]$. To improve the durable fire resistance of the treated cotton, MDPA has been used with TMM $[2,10]$. There has been a great debate about the environmental impacts related to the use of organophosphorus MPDA product because of the high level of formaldehyde release when combining MDPA and TMM $[6,10]$.

To reduce the formaldehyde-free content of the flame retardant treated fabric, in our previous study [11], Pyrovatex CP New (PR) has been used as flame retardant agent, Citric acid (CA) and Knittex FFRC (modified DHEU) have been used as formaldehydefree cross-linking agents [12]. The previous results [11] showed that the use of CA was more favourable than using Knittex FFRC (K). Because CA created the ester bond with $\mathrm{PR}$ and cellulose, while Knittex FFRC (DHEU) created the ether bond. However, ester bonds are more susceptible to hydrolysis in water than ether bonds [13], resulting in less durable fire resistance to washing. Beside the impact of DHEU on the tensile strength of the cotton fabric was also lower in comparison with CA. For these reasons, Knittex FFRC (K) was chosen for further research. However, how much of this substance should be used to get the best results?

In reality, there is a very limited research on the formulation and optimization of FR application processes, especially there is no study on optimal concentration of PR and K. Therefore, a study of the effect of $\mathrm{PR}$ and $\mathrm{K}$ concentrations on the properties of treated cotton fabrics is necessary to obtain their optimal content. In the traditional methodology, each factor is changed in turn to observe their impacts on the properties of the treated fabric as in the study of Mengal $\mathrm{N}$ [7]. Therefore, this method does not allow observing the simultaneous effects of factors and their interactions on the fabric properties. In recent years, several studies have applied the response surface methodology (RSM) to find the relationship between the controlled experimental factors and the observed results $[1,14]$. Before applying the RSM, it is necessary to select an experimental design, which provides information on the number of experiments that need to be performed in the experimental region being studied. Experimental design for first-order models like factorial design can be used when the data set does not display curvature. If the response function cannot be described by linear functions, the other designs for quadratic response surfaces should be used such as three-level factorial, Box-Behnken, central composite and Doehlert designs etc. [14-16]. This method allows observing the simultaneous and interactive effects of many factors on the results. Moreover, it also allows achieving the optimal value of technological parameters with a minimum number of experiments.

In this study, a central composite designs type face centred (CCF) with RSM was used to optimize the $\mathrm{PR}$ and $\mathrm{K}$ concentrations in flame retardant finishing for cotton fabric. The flame retardancy, tensile strength and formaldehyde-free content of the treated fabric were measured as the functions of Pyrovatex CP New and Knittex FFRC (DHEU) concentrations. The purpose of the study is to predict the optimal Pyrovatex CP New and Knittex FFRC concentrations with the highest fire resistance efficiency, minimum loss for mechanical properties and minimum formaldehyde release for the treated fabric.

The news of this study is application of the CCF design with RSM to get the optimal concentrations of Pyrovatex CP New and Knittex FFRC in flame retardant finishing for cotton fabric.

\section{MATERIALS AND METHODS}

\section{Materials}

The $100 \%$ cotton twill fabric with surface mass of 190 $\mathrm{g} / \mathrm{m}^{2}$ was supplied by Hanoi Dyeing Joint Stock Company, Vietnam. The fabric was desized, scoured, bleached and mercerized. Pyrovatex CP New (PR), Knittex FFRC (K), Invadine PBN were supplied by Huntsman. Pyrovatex CP New (PR) is an N-methylol dimethylphosphonpropionamide, in this study, it was used as a flame-retardant agent. Knittex FFRC is a modified dihydroxy ethylene urea, it was used as a cross-linking agent. Invadine PBN was used as tenside surfactant.

\section{Methods}

\section{Flame retardant treatment for cotton fabric}

The pad-dry-cure technique was applied to finish fabrics with different finishing formulations that contain Pyrovatex CP New (PR), Knittex FFRC (K) and Invadine PBN. The reaction mechanism describes the link between cellulose (cotton) and Pyrovatex CP New through DHEU (Knittex FFRC) as cross-linking agent was presented in [11].

In this work, the concentration of Invadine PBN was $5 \mathrm{~g} / \mathrm{l}$ for all experiments, while the concentrations of Pyrovatex CP New (PR) and Knittex FFRC (K) have been varied according to the options presented in table 1 (they were determined according to the 
selected test design, it was central composite designs type face centred (CCF)).

All experiments were carried out under the same conditions: the samples were padded with a wet pickup of approximately $80 \%$ by padder SDL D394A, then dried at $110^{\circ} \mathrm{C}$ for 5 minutes and cured at $180^{\circ} \mathrm{C}$ for 2 minutes by stenter SDL D398. Next, the samples were washed under running water for 5 minutes and dried in the stenter at $110^{\circ} \mathrm{C}$ for 3 minutes. The detail of the characteristics of cotton fabric, chemical formulas of the main agents and the flame-retardant treatment process was presented in our previous study [11].

Assessment of fabric's properties

The fire-retardant effect of treated fabric was assessed through the following characteristics: The real uptake of recipe chemicals (add-on \%) on fabric, the characteristics of the vertical flammability test and the limiting oxygen index (LOI).

The real uptake of recipe chemicals (add-on \%) on the treated fabric was calculated using equation 1 and the results are presented in table 2 .

$$
\text { Add-on }(\%)=\frac{W_{F}-W_{0}}{W_{0}} \cdot 100
$$

In equation $1, W_{F}$ is the standard condition weight of the treated sample, and $W_{0}$ is the standard condition weight of the untreated sample. The test was repeated six times for each experiment. The final result is an average of the 6 measures.

The Vertical flammability test method ASTM D 64132015 [17] was used for evaluating the flammability of untreated and finished samples.

The LOI value of the control and finished samples were measured in accordance with the ASTM D 2863-97 standard method [18].

Tensile strength of the un-treated and treated samples was determined according to the ISO 13934-1: 2013 standard method [19] to assess the loss of mechanical strength of the fabric due to the flame retardant treatment.

The formaldehyde-free content of flame retardant finished specimens was tested to control the ecological property of the treated fabrics. It was measured with the reference to the guidelines given in the EN ISO 14184-1:1998 standard [20].

\section{Experimental design}

In this work, the statistical design was carried out considering two factors: PR concentration and $\mathrm{K}$ concentration as process parameters to maximize addon amount, LOI value, warp tensile strength (Warp TS), weft tensile strength (Weft TS) and to minimize the formaldehyde-free content (FFC) of the treated fabric.

Based on the results of the works $[6,7]$ and our previous study [11], in this study, the variation range of the concentration of PR was chosen from $350 \mathrm{~g} / \mathrm{l}$ to $450 \mathrm{~g} / \mathrm{l}$, and the concentration of $\mathrm{K}$ was changed from $80 \mathrm{~g} / \mathrm{l}$ to $120 \mathrm{~g} / \mathrm{l}$.

According to the face-centred central-composite designs, axial points are located at a distance 1 from the centre point, i.e., factors are tested at 3 levels minimum, middle and maximum, equivalent to levels $-1,0$ and +1 (which are called coded units) [16]. If $X_{\min }$ and $X_{\max }$ are respectively minimum and maximum absolute, i.e., un-coded values of a factor, the absolute values $X$ corresponding the respective coded values can be obtained by a simple linear transformation of the original measurement scale, namely [16]:

$$
X=\Delta_{X} \cdot \text { coded value }+X_{0}
$$

where $X_{0}=\left(X_{\min }+X_{\max }\right) / 2, \Delta_{X}=\left(X_{\max }-X_{\min }\right) / 2$.

The relationship between the coded variables and un-coded variables is described by the following equations:

$$
A(B)=\left(X_{i}-X_{0}\right) / \Delta_{X}
$$

where $X_{i}$ are the un-coded variables and $A(B)$ are the coded variables. Obviously, un-coded factors have their own units. By introducing coded variables, we make the factors dimensionless [16].

According to the CCF, the total number of experimental trials, based on the number of design factors $k=2$, was equal to $N=2^{k}+2 k+n_{c}=10$ [16]. Where $k$ is number of factors studied in the experiment, $2^{k}$ factorial trials, $2 k$ - axial trials and $n_{c}$ - centre point trials $\left(n_{c}=k\right)$. Table 1 shows the experiments designed with $\mathrm{PR}$ and $\mathrm{K}$ concentrations determined according to CCF.

\begin{tabular}{|c|c|c|c|c|}
\hline \multicolumn{6}{|c|}{ DESIGNED EXPERIMENTS USING CCF } \\
\hline Exper. no. & A & B & $\mathbf{X}_{\mathbf{1}}$ (g/l) & $\mathbf{X}_{\mathbf{2}}$ (g/l) \\
\hline 1 & +1 & +1 & 450 & 120 \\
\hline 2 & -1 & 0 & 350 & 100 \\
\hline 3 & +1 & 0 & 450 & 100 \\
\hline 4 & -1 & +1 & 350 & 120 \\
\hline 5 & -1 & -1 & 350 & 80 \\
\hline 6 & 0 & +1 & 400 & 120 \\
\hline 7 & 0 & -1 & 400 & 80 \\
\hline 8 & +1 & -1 & 450 & 80 \\
\hline 9 & 0 & 0 & 400 & 100 \\
\hline 10 & 0 & 0 & 400 & 100 \\
\hline
\end{tabular}

The influence of the variables on the results including real uptake of recipe chemicals (add-on\%) on fabric, limiting oxygen index (LOI value), the tensile strength of the treated fabric were adjusted using equation 4 [15].

$$
Y=b_{0}+\sum b_{i} X_{i}+\sum b_{i j} X_{i} X_{j}+\sum c_{i} X_{i}^{2}
$$

In this equation, $i \geq j, i, j=1,2,3, Y$ is add-on (\%) on fabric, limiting oxygen index (LOI value), fabric tensile strength in the warp and weft directions.

$X_{i}(i=1,2)$ and $X(j=1,2)$ are independent variables, and $b_{0}, b_{i}$, and $b_{i j}(i=1,2)$, and $c_{i}(i=1,2$ and $\mathrm{j}=1$, $2)$ are the coefficients of the model obtained using polynomial regression. The Design Expert V 10.0.8 
(US, Stat-Ease Inc.) software was used to evaluate these relationships.

\section{RESULTS AND DISCUSSION}

The experimental results according to the CCF design are presented in the table 2. In the table $2 \mathrm{Y} 1$, Y2, Y3 and Y4 are the anticipated responses for the add-on (\%), LOI value, warp tensile strength, weft tensile strength.

\section{Model determination}

From the experimental results, the equations $\mathrm{Y}$ 1, $\mathrm{Y}$ 2, Y3 and Y4 respectively were output by the Design Expert $\mathrm{V}$ 10.0.8, they are linear equations for $\mathrm{Y} 1, \mathrm{Y} 2$ and $Y 4$ and quadratic equation for $Y 3$. The equations of $\mathrm{Y} 1, \mathrm{Y} 2, \mathrm{Y} 3, \mathrm{Y} 4$ and their statistical parameters are shown in table 3 . The shorted ANOVA related to the Y1, Y2, Y3, Y4 models are given in table 4.

Model fitting and analysis of variance (ANOVA)

The coefficient of determination $\left(R^{2}\right)$ is a measure of the degree of fit of the models. Sohail et al. [9] suggested that model with $R^{2}$ values above 0.6 is viewed as legitimate or a valid model. While Qiu et al. [21] proposed that a good model fit should yield an $\mathrm{R}^{2}$ of at least 0.8 . In addition, the variety of probability $(p)>F$ estimations of a model also demonstrate the significance of the model: The lower the p-value is, the higher the model's significance becomes. Qiu et al. [21] proposed that a p-value lower than 0.05 indicates that the model is statistically significant, whereas a P-value higher than 0.1000 indicates that the model is not significant. Pure error lack-of-fit test is also used to assess whether the model is adequate

Table 2

\begin{tabular}{|c|c|c|c|c|c|c|c|c|c|c|}
\hline \multicolumn{11}{|c|}{ THE CCF EXPERIMENTAL DESIGN AND RESULTS } \\
\hline \multirow[b]{3}{*}{ Run } & \multicolumn{2}{|c|}{ Variable factor } & \multicolumn{8}{|c|}{ Properties of fabric } \\
\hline & \multirow[b]{2}{*}{$\begin{array}{c}X_{1} P R \\
\text { conc. } \\
(g / l)\end{array}$} & \multirow[b]{2}{*}{$\begin{array}{c}X_{2} K \\
\text { conc. } \\
(g / l)\end{array}$} & \multirow[b]{2}{*}{$\begin{array}{c}Y_{1} \text { add-on } \\
\%\end{array}$} & \multirow[b]{2}{*}{$\begin{array}{c}Y_{2} \text { LOI } \\
\%\end{array}$} & \multicolumn{3}{|c|}{$\begin{array}{l}\text { Characteristics of vertical } \\
\text { flammability test }\end{array}$} & \multicolumn{2}{|c|}{$\begin{array}{c}\text { Tensile strength } \\
\text { test }\end{array}$} & \multirow[b]{2}{*}{$\begin{array}{c}\text { Formal- } \\
\text { dehyde-free } \\
\text { content } \\
\text { (mg/kg) }\end{array}$} \\
\hline & & & & & $\begin{array}{l}\text { After-flame } \\
\text { times } \\
\text { (s) }\end{array}$ & $\begin{array}{l}\text { After-glow } \\
\text { times } \\
\text { (s) }\end{array}$ & $\begin{array}{l}\text { Char } \\
\text { length } \\
(\mathrm{mm})\end{array}$ & $\begin{array}{c}\mathrm{Y}_{3} \text { warp } \\
\text { tensile } \\
\text { strength } \\
(\mathrm{N}) \\
\end{array}$ & $\begin{array}{c}\mathrm{Y}_{4} \text { weft } \\
\text { tensile } \\
\text { strength } \\
(\mathrm{N})\end{array}$ & \\
\hline Control & - & - & - & 14.9 & 23 & 44 & $\begin{array}{c}\text { Completely } \\
\text { burned }\end{array}$ & 899.3 & 532.8 & - \\
\hline S1 & 450 & 120 & 15.54 & 26.3 & 0 & 0 & $59 \pm 6$ & 631.69 & 435.19 & 290.86 \\
\hline S2 & 350 & 100 & 12.94 & 23.2 & $2 \pm 1$ & 0 & $69 \pm 6$ & 588.72 & 407.04 & 249.13 \\
\hline S3 & 450 & 100 & 14.99 & 25.9 & 0 & 0 & $70 \pm 2$ & 622.68 & 421.22 & 236.1 \\
\hline S4 & 350 & 120 & 13.67 & 23.7 & $5 \pm 2$ & 0 & $104 \pm 16$ & 603.55 & 400.33 & 266.03 \\
\hline S5 & 350 & 80 & 12.55 & 23.2 & $5 \pm 2$ & 0 & $100 \pm 22$ & 528.52 & 415.57 & 213.32 \\
\hline S6 & 400 & 120 & 14.36 & 24.1 & 2 & 0 & $59 \pm 5$ & 630.11 & 406.05 & 244.17 \\
\hline S7 & 400 & 80 & 12.80 & 23.7 & 0 & 0 & $66 \pm 4$ & 581.32 & 439.66 & 282.93 \\
\hline S8 & 450 & 80 & 13.94 & 25.0 & 2 & 0 & $64 \pm 6$ & 579.65 & 448.48 & 205.76 \\
\hline S9 & 400 & 100 & 13.01 & 24.1 & $4 \pm 2$ & 0 & $107 \pm 30$ & 628.23 & 421.88 & 292.35 \\
\hline $\mathrm{S} 10$ & 400 & 100 & 13.14 & 24.6 & - & - & - & 622.15 & 424.99 & - \\
\hline
\end{tabular}

\begin{tabular}{|c|c|c|c|c|c|}
\hline \multicolumn{6}{|c|}{ MODEL FITTING OF TEST RESULTS } \\
\hline \multirow{2}{*}{ Test responses } & \multicolumn{4}{|c|}{ Model Parameter } & \multirow{2}{*}{$\begin{array}{l}\text { Response equation } \\
\text { in actual variable }\end{array}$} \\
\hline & R-squared & Adj R-squared & F-value & P-value & \\
\hline Add-on & 0.8573 & 0.8165 & 21.02 & 0.0011 & $\begin{array}{c}\mathrm{Y} 1=3.04733+0.017700 \mathrm{X}_{1}+ \\
+0.035667 \mathrm{X}_{2} \quad(\mathrm{Y} 1)\end{array}$ \\
\hline LOI & 0.8944 & 0.8642 & 29.63 & 0.0004 & $\begin{array}{c}\mathrm{Y} 2=13.08000+0.023667 \mathrm{X}_{1} \\
+0.018333 \mathrm{X}_{2}\end{array}$ \\
\hline Warp tensile strength & 0.9895 & 0.9764 & 75.43 & 0.0005 & $\begin{array}{l}Y 3=-1655.30619+7.25710 X_{1}+ \\
+13.60843 X_{2}-0.0057475 X_{1} X_{2}- \\
-0.00788114 X_{1}^{2}-0.049220 X_{2}^{2} \text { (Y3) }\end{array}$ \\
\hline Weft tensile strength & 0.8065 & 0.7513 & 14.59 & 0.0032 & $\begin{array}{c}\mathrm{Y} 4=364.55767+0.27317 \mathrm{X}_{1}- \\
-0.51783 \mathrm{X}_{2}\end{array}$ \\
\hline
\end{tabular}


Table 4

\begin{tabular}{|c|c|c|}
\hline \multicolumn{3}{|c|}{ SHORTED ANOVA OF THE MODELS } \\
\hline Source & F-value & p-Value Probe $>F$ \\
\hline Model & \multicolumn{2}{|r|}{ Y1 } \\
\hline A-PR CONTENT & 25.48 & 0.0015 \\
\hline B-K CONTENT & 16.56 & 0.0048 \\
\hline Lack of Fit & 25.29 & 0.1510 \\
\hline Model & \multicolumn{2}{|r|}{ Y2 } \\
\hline A-PR CONTENT & 54.07 & 0.0002 \\
\hline B-K CONTENT & 5.19 & 0.0568 \\
\hline Lack of Fit & 1.28 & 0.5886 \\
\hline Model & \multicolumn{2}{|r|}{ Y3 } \\
\hline A-PR CONTENT & 83.99 & 0.0008 \\
\hline B-K CONTENT & 202.59 & 0.0001 \\
\hline$A B$ & 5.19 & 0.0849 \\
\hline$A^{2}$ & 35.60 & 0.0040 \\
\hline $\mathrm{B}^{2}$ & 35.55 & 0.0040 \\
\hline Lack of Fit & 1.50 & 0.5257 \\
\hline Model & \multicolumn{2}{|r|}{ Y4 } \\
\hline A-PR CONTENT & 18.53 & 0.0035 \\
\hline B-K CONTENT & 10.65 & 0.0138 \\
\hline Lack of Fit & 14.41 & 0.1990 \\
\hline
\end{tabular}

to describe the functional relationships between the experimental factors and the response. Low p-value for lack-of-fit in ANOVA table means that the analysed model does not fit to the experimental data [16]. Table 3 shows that the coefficients of determination $\left(R^{2}\right)$ of all four responses are higher than 0.8 . Furthermore, their $p$-values are less than 0.05 in all responses indicating that all four models are highly significant. Besides, in the table 4, the calculated p-values for lack-of-fit are greater than 0.05 for all modes $Y 1, Y 2, Y 3, Y 4$. Therefore, there is no statistically significant evidence that these models do not represent the data at a 95\% confidence level.

Statistical significance of the terms of the models

The statistical significance of the terms of the model defined by equation 4 can be evaluated using the analysis of variance (ANOVA). A statistical F-test is employed to identify statistically significant terms of the model. One can obtain p-values from this test for each term of the model, which are a measure of the probability of obtaining data at least as extreme as the data from the model. The lower the p-values for the analysed terms are, the greater the effect these terms have on the response predicted by the model [16]. As well as for the model, a p-value of the terms lower than 0.05 indicates that the term is statistically significant, whereas a $p$-value higher than 0.1000 indicates that the term is not significant [16, 21]. Table 4 shows that, all the $p$-values of the terms of $Y 1$ and $Y 4$ are less than 0.05 , which means that the coefficients of the terms in these models are significant. Meanwhile, one $\mathrm{p}$-value of $\mathrm{Y} 3$ and one $\mathrm{p}$-value of $\mathrm{Y} 2$ are higher than 0.05 , but they are less than 0.1 , so, according to the above-mentioned principle, they can be accepted. As such, all terms of these four models are accepted.

All these four models are significant for the further analyses

\section{Effect of PR and $K$ concentrations on the properties of the finished fabric}

Effect of $P R$ and $K$ concentrations on the real uptake of the finished fabrics

The fitted model of the add-on in un-coded variables is presented in equation $\mathrm{Y} 1$ (table 3 ) and in coded variables is showed in equation y1. Figure 1 shows the response surface curve of the add-on.

$$
\text { add-on }=13.69+0.88 A+0.71 B
$$

From the equation $\mathrm{y} 1$, it can be seen that, in the studied range of the factors, the relationships between both factors and the add-on on the treated samples are linear. The concentrations of $\mathrm{PR}$ and $\mathrm{K}$ used in the finishing solution are effective factors on the addon of the treated fabric. The higher the concentrations of $P R$ and $K$ are, the higher the add-on on the samples is. However, the coefficient of factor $A$ is slightly higher than the coefficient of factor $B$ indicating that the effect of the PR factor on the add-on amount is greater than that of the $\mathrm{K}$ factor. Figure 1 and equation $\mathrm{y} 1$ indicate that the highest add-on amount is related to the sample treated with $450 \mathrm{~g} / \mathrm{l}$ of PR and $120 \mathrm{~g} / \mathrm{l}$ of $\mathrm{K}$.

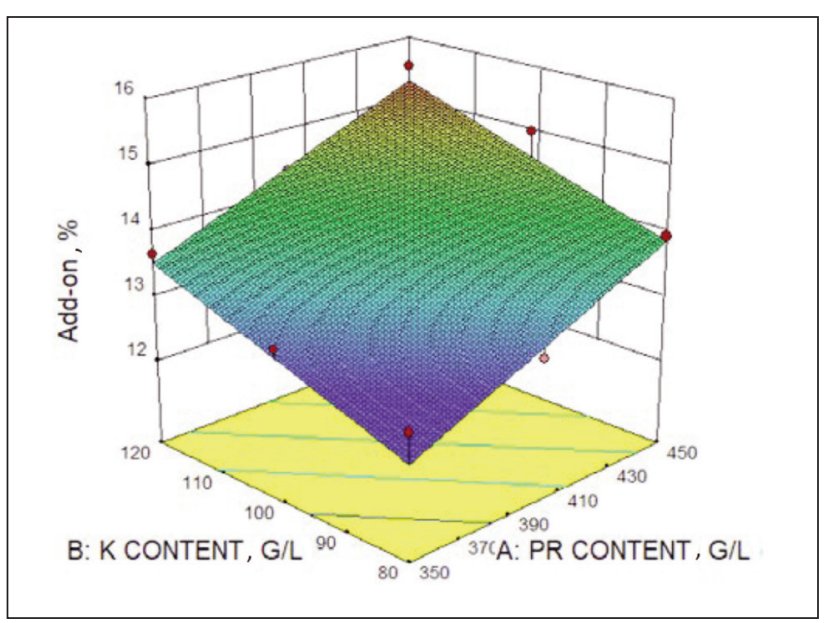

Fig. 1. Surface response curve related to add-on of samples

Effect of the chemical content on LOI value of the treated fabric

The fitted model for describing the relationship between the LOI value of the treated fabric and the $\mathrm{PR}$ and $\mathrm{K}$ concentrations in un-coded variables is presented in equation Y2 (table 3 ) and in coded variables is equation y2. Figure 2 shows the response surface curve of the LOI.

$$
\mathrm{LOI}=24.38+1.18 A+0.37 B
$$

Equation y2 and figure 2 show that, similar to the value of add-on, LOI of the treated fabrics has a linear relationship that is directly proportional to both 


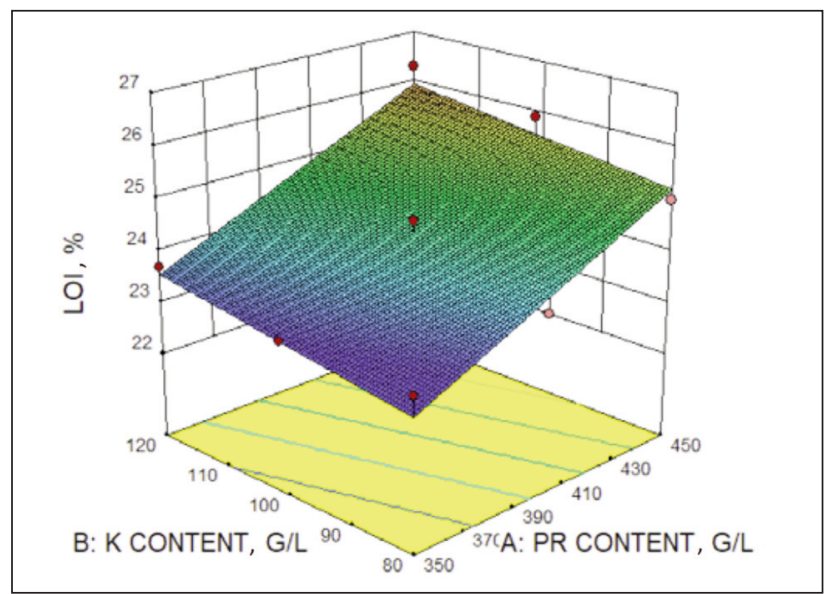

Fig. 2. Surface response curve related to LOI value of treated samples

PR and $\mathrm{K}$. Thus, the highest LOI value is also related to the sample treated with the highest concentrations of PR $(450 \mathrm{~g} / \mathrm{l})$ and $\mathrm{K}(120 \mathrm{~g} / \mathrm{l})$. However, in the equation $y 2$, the coefficient of factor $A$ is 1.18 while the one of factor $B$ is only 0.37 indicating that the effect of PR to LOI is much greater than that of $\mathrm{K}$.

Effect of the chemical content on the flammability of finished fabric

The results of flammability test of samples according to the test method ASTM D 6413-2015 are presented in table 2 (after-flame time, afterglow time and char length). Figure 3 shows the after-flame time of the samples treated with the different finishing formulations and figure 4 shows the images of the samples after the vertical flammability test.

The results show good effect of flame-retardant treatment on the cotton fabric. There is a clear difference in combustion behaviour between untreated and treated samples in the vertical flammability testing. The control sample (figure 4) burned vigorously in directly exposure to the ignition source. After removing the combustion source, the sample continued to burn until it had burned out and no char at all. Furthermore, there was 44 seconds of afterglow. While all the treated fabrics were self-extinguished after removing the combustion source. Moreover,

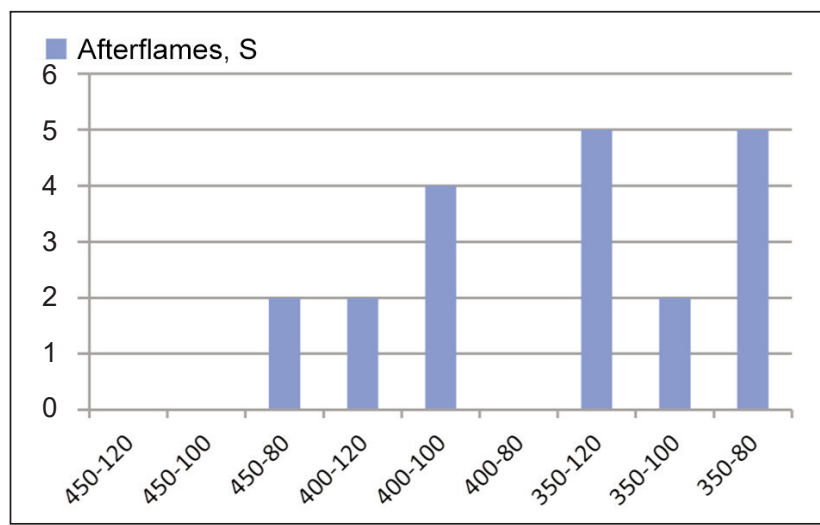

Fig. 3. After-flame time of the treated samples under ASTM D6413 test

there were char-forming on the sample areas exposed to the flame (figure 4). Besides, the burning behaviour of the treated samples under the vertical flammability test also varied depending on the formulation of their finished solution. The graph of figure 3 shows that the samples treated at the highest concentration of PR $(450 \mathrm{~g} / \mathrm{l})$ have the shortest afterflame time (zero, zero and 2 seconds), the samples treated at the lowest concentration of PR $(350 \mathrm{~g} / \mathrm{l})$ have the longest after-flame time $(5,2$ and 5 seconds), that of samples treated at $400 \mathrm{~g} / \mathrm{l}$ of PR are 2 , 4 and zero seconds. Although there is no fitted model between after-flame time and 2 factors $A$ and $B$, but their values have also varied relatively according to the changes of these factors.

The best vertical flammability characteristics are also related to the samples treated with the PR concentration of $450 \mathrm{~g} / \mathrm{l}$ and $\mathrm{K}$ concentration of 120 or $100 \mathrm{~g} / \mathrm{l}$. Influence of the chemical content on tensile strength of cotton fabric

Firstly, the fabric density was tested in the treated samples, the result showed that the density of the treated fabrics stays unchanged in comparison with the control fabric. Therefore, the tensile strength of fabric samples that presented in the table 2 was used to assess the influence of flame-retardant treatment on the tensile strength of cotton fabric.

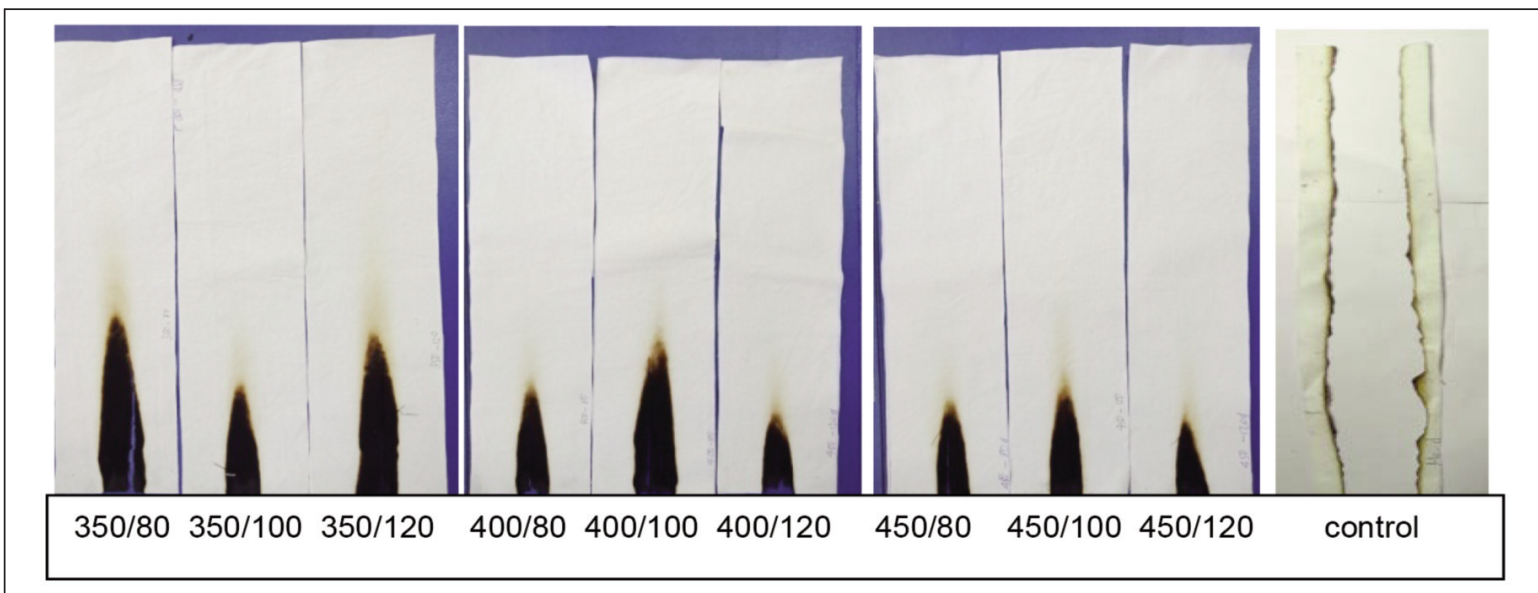

Fig. 4. Treated and control samples after vertical flammability test 
The results of table 2 show that the tensile strength of the treated samples was significantly reduced compared to the untreated samples. This mechanical strength loss in the direction of warp yarn is in the range of 30 to $41 \%$, while, in the direction of the weft, it is lower, from 18 to $25 \%$.

Based on the values of tensile strength of the treated samples and the data of experimental design, the Design Expert software $\mathrm{V}$ 10.0.8 has been found the fitted models between two factors and the tensile strength of the treated fabric in warp and weft yarns direction, which are the equation Y3 and Y4 (table 3). The fitted model of the warp tensile strength in coded variables is presented in equation y3. The response surface curve of warp tensile strength of the samples is showed in figure 5.

$$
\begin{aligned}
\text { Warp TS }= & 625.30+18.87 A+29.3-5.75 A B- \\
- & 19.7 A^{2}-19.69 B^{2}
\end{aligned}
$$

Equation y3 is a fully quadratic equation, the model takes into account linear effects, quadratic effects and two-way interactions between the studied factors. This means that the model has the maximum point within the studied range of these two variables. First, when the concentrations of PR and $\mathrm{K}$ increased, the warp tensile strength of the treated fabric increased. Then, it decreased while these two factors continued to increase. The highest warp tensile strength can be $638.63 \mathrm{~N}$, it is related to the sample treated with $413.75 \mathrm{~g} / \mathrm{l}$ of PR and $112.5 \mathrm{~g} / \mathrm{l}$ of $\mathrm{K}$.

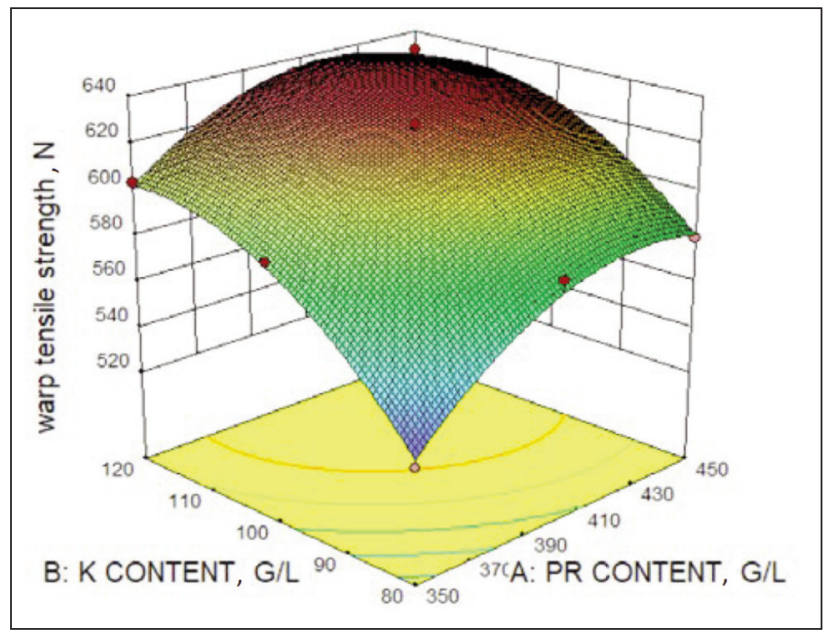

Fig. 5. Surface response curve related to warp tensile strength of treated samples

It could be suggested that, this loss of tensile strength of the fire-retardant treated cotton fabric may be mainly due to high temperature treatment. Beside the used chemicals can also affect to the mechanical strength of fabric, but it could be due to two opposite effects. First, the add-on on the treated fabric, linked to the fabric by covalent bonding, which could help to increase the tensile strength of the treated fabric. Secondly, the acidic effect of the used chemicals could reduce the mechanical strength of the fabric (both chemicals have low $\mathrm{pH}$ : $\mathrm{pH}$ of solution $100 \mathrm{~g} / \mathrm{l}$
$\mathrm{PR}$ is $3.5 \div 6.0$ and $\mathrm{pH}$ of $\mathrm{K}$ is $2.2 \div 3.5$ ). When the second effect was stronger than the first one, the fabric strength began to decrease. Perhaps, when the concentration of chemical agents was too high, the acid effect could be stronger than other effects and the mechanical strength of the fabric began to decrease. The fitted model of the weft tensile strength in coded variables is presented in equation y4. The response surface curve of weft tensile strength of the samples is showed in figure 6 .

$$
\text { Weft TS }=422.04+13.66 A-10.36 B
$$

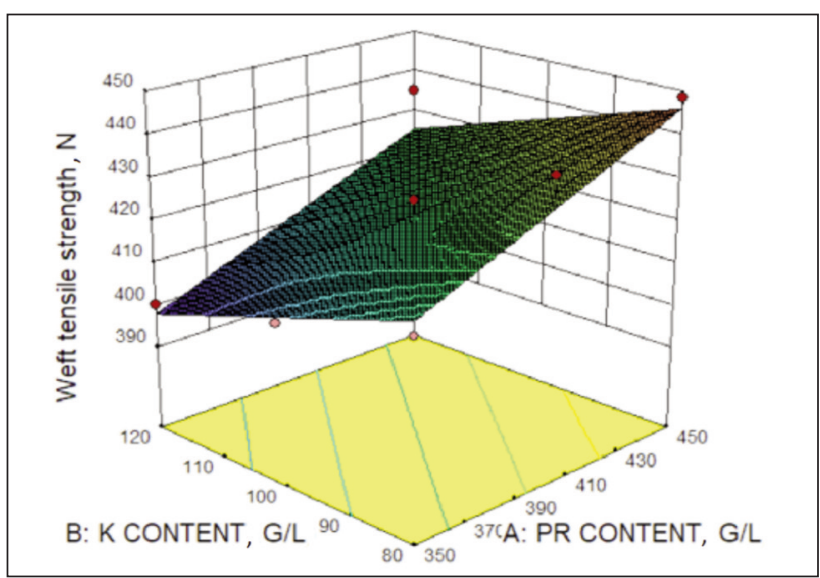

Fig. 6. Surface response curve related to weft tensile strength of samples

The equation y4 and figure 6 show that the response model of the weft tensile strength of the treated samples is based on two linear effects. One is the positive effect related to the PR concentration, the other is the inverse effect related to $\mathrm{K}$ concentration. That means, the higher the PR concentration is, the higher the weft tensile strength of treated fabric is. In contrast, the higher the concentration of $\mathrm{K}$ is, the lower the weft tensile strength of treated fabric becomes. Therefore, the highest weft tensile strength is related to the sample treated with $450 \mathrm{~g} / \mathrm{l}$ of PR and $80 \mathrm{~g} / \mathrm{l}$ of $\mathrm{K}$. It is assumed that this phenomenon may also be related to the add-on on the treated samples and the acidity of the chemicals was used. In which, the increase in the tensile strength when increasing the PR content may be greater than the reduction due to the decrease in the $\mathrm{pH}$ of the finished solution. In contrast, the increase in the tensile strength when increasing the $\mathrm{K}$ content may be smaller than the reduction due to the decrease in the $\mathrm{pH}$ of the padding solution. This hypothesis can be accepted thanks to the following phenomena: Firstly, in equation $\mathrm{y} 1$, the coefficient of PR factor is higher than that of factor K. Secondly, the $\mathrm{pH}$ of $\mathrm{K}$ is lower than that of PR

Influence of chemical concentrations on formaldehyde-free content (FFC) of the treated fabric

Results of the hydrolyzed formaldehyde amounts of the treated samples are presented in table 2. The results of table 2 show that the formaldehyde-free content of un-treated sample is only $23 \mathrm{ppm}$. While it is from 205.76 to 292.35 ppm for all treated samples. 
Knitex FFRC is a formaldehyde-free crosslinking agent. Therefore, the FFC of the treated samples could be mainly from Pyrovatex CP New [8]. Although the fitted model between FFC and 2 factors $A$ and $B$ has not been found, however, the formaldehyde-free content of all the treated samples is less than 300 ppm, it fulfills the criterion of OEKO-TEX® standard 100 for not direct skin apparel fabrics.

\section{Optimizing content of Pyrovatex CP New and Knittex FFRC}

The best PR and $\mathrm{K}$ concentrations focusing individual parameters are presented in the table 5 . The errors calculated between the related experimental and the predicted values were relatively small indicating the adequacy of the models. The best processing conditions for each individual parameter are not the same. Therefore, it is necessary to find the optimal PR and $\mathrm{K}$ concentrations when combining all these characteristics, because there is no fitted model for afterflame time and formaldehyde-free content of the treated samples. The add-on is only an indirect parameter to predict the fire resistance of the fabric.

Therefore, the optimal concentrations of PR and $\mathrm{K}$ were determined when combining only 3 parameters of treated samples (LOI value, warp and weft tensile strength).

The optimal concentrations of PR and $\mathrm{K}$ were investigated from the numerical optimization approach with the assistance of software Design-Expert form. As the aim of this study was to obtain the fabric to have the highest flame resistance, maximum mechanical properties. Moreover, in this study, the LOI value of fabric was preferred over the tensile strength of the fabric. Therefore, the importance of the LOI, warp and weft tensile strength has been chosen as 5, 3 and 3 respectively. According to these criteria, Design-Expert software has given the optimal concentrations of $\mathrm{PR}$ and $\mathrm{K}$ and predicted the LOI values, tensile strength in the warp and weft direction of the cotton fabrics when they would be treated in this condition (table 6). From table 6, if the cotton fabric is treated at the optimal concentrations of $\mathrm{PR}$ and $\mathrm{K}$, it will have a LOI value of $25.7 \%$, the tensile strength of the fabric in the warp and weft directions will be $630.5 \mathrm{~N}$ and $431.7 \mathrm{~N}$. It shows that if the cotton fabric is treated at this condition, it can be classified as flame retardant fabric with a LOI value higher than $25 \%$ [22]. The other properties of the fabrics (afterflame time, afterglow time, tensile strength) also can meet the requirements of fabrics for the protective clothing against heat and fire according to ISO 11612:2008 [23].

\section{CONCLUSION}

In this work, a response surface methodology with CCF experimental design was employed to study the effects of reagent concentrations on the finishing process and optimization of the parameters to attain the optimal formulation.

Four response models between reagent concentrations and the add-on amount, LOI value, warp and weft tensile strength of the treated fabric have been obtained. The R-squared values of these models were above 0.8 confirming that these models were significant. The experimental estimations at the best selected conditions (table 5) were comparably similar to the predicted values in the formulation. That indicates the adequacy of the models.

The optimum conditions selected for the combined parameters are $450 \mathrm{~g} / \mathrm{l} \mathrm{PR}$ and $107 \mathrm{~g} / \mathrm{l} \mathrm{K}$. Cotton fabrics treated under these conditions can meet the criteria of flame-retardant fabrics for professional use. It also fulfils the criterion for formaldehyde-free content (<300 ppm) of OEKO-TEX® standard 100 for not direct skin apparel fabrics.

However, the high mechanical strength loss of fabric due to the flame-retardant treatment is still a limitation of this study. This may be due not only to the use of chemicals but also to cotton fabric heated at high temperatures for a long time (at $180^{\circ} \mathrm{C}$ for $120 \mathrm{sec}-$ onds). Therefore, to minimize this limitation, it is necessary to determine the optimal curing conditions. This is the lowest possible curing condition to create a cross-linking between cellulose and PR. This content will be implemented in our further studies.

\begin{tabular}{|c|c|c|c|c|c|}
\hline \multicolumn{6}{|c|}{ THE BEST FORMULATIONS OF THE FINISHING SOLUTION FOR INDIVIDUAL PARAMETERS } \\
\hline Goal & PR con. (g/l) & K con. (g/l) & Predicted values & Actual values & Error (\%) \\
\hline Max Warp TS (N) & 413.75 & 112.5 & 638.63 & - & - \\
\hline Max Weft TS (N) & 450 & 80 & 446.056 & 448.48 & -0.5 \\
\hline Max Add-on (\%) & 450 & 120 & 15.412 & 15.54 & -0.82 \\
\hline Max LOI (\%) & 450 & 120 & 25.93 & 26.3 & 1.4 \\
\hline
\end{tabular}

Table 6

\begin{tabular}{|c|c|c|c|c|c|c|c|}
\hline \multicolumn{7}{|c|}{ OPTIMIZED FORMULATIONS OF THE FINISHING SOLUTION FOR COMBINED PARAMETERS } \\
\hline Number & $\begin{array}{c}\text { PR content } \\
(\mathbf{g} / \mathbf{l})\end{array}$ & $\begin{array}{c}\text { K content } \\
(\mathbf{g} / \mathbf{l})\end{array}$ & $\begin{array}{c}\text { Warp tensile } \\
\text { strength } \\
(\mathbf{N})\end{array}$ & $\begin{array}{c}\text { Weft tensile } \\
\text { strength } \\
(\mathbf{N})\end{array}$ & LOI & Desirability & Number \\
\hline 1 & 450.000 & 107.575 & 630.565 & 431.777 & 25.702 & 0.805 & Selected \\
\hline
\end{tabular}




\section{Acknowledgments}

This work was comprehended in the framework of project KC.02.13/16-20 which is financed by the MOST of Vietnam. The authors wish to sincerely thank MOST of
Vietnam, KC.02/16-20 program, Chemical-textile LAB, Testing center of textile-leather materials and Laboratory of Polymer and Composite Materials of HUST for supports during our research.

\title{
REFERENCES
}

[1] Cheema, H.A., El-Shafei, A., Hauser, P.J., Conferring flame retardancy on cotton using novel halogen-free flame retardant bifunctional monomers: synthesis, characterizations and applications, In: Carbohydrate polymers, 2013, 92, 1, 885-893

[2] Visakh, P.M., Flame retardants, Engineering Materials, London, 2015

[3] Prinz, K., Flame retardant and dyeing treatment of cellulose fabrics using a combined "grafting from" and PIGP process., Eth Zurich, Zurich, 2011

[4] Yoshioka-Tarver, M., et al., Influence of NP Base Fiber Reactive Organophosphorus Flame Retardant on Cotton Thermal Behavior, In: AATCC Review: the magazine of the textile dyeing, printing, and finishing industry, 2012, 12, $5,52-59$

[5] Saleem, S., A method of chemical aftertreatment for the reduction of free formaldehyde release of a durable flame retardant finished cotton fabric, 2015

[6] Mohsin, M., Ahmad, S.W., Khatri, A., Zahid, B., Performance enhancement of fire retardant finish with environment friendly bio cross-linker for cotton, In: Journal of Cleaner Production, 2013, 51, 191-195

[7] Mengal, N., Syed, U., Malik, S.A., Ali Sahito, I., Jeong, S.H., Citric acid based durable and sustainable flame retardant treatment for lyocell fabric, In: Carbohydr. Polym., 2016, 153, 78-88

[8] Katović, D., Grgac, S.F., Bischof-Vukušić, S., Katović, A., Formaldehyde free binding system for flame retardant finishing of cotton fabrics, In: Fibres \& textiles in Eastern Europe, 2012, 1, 90, 94-98

[9] El-Hady, M.M.A., Farouk, A., Sharaf, S., Flame retardancy and UV protection of cotton based fabrics using nano ZnO and polycarboxylic acids, In: Carbohydrate Polymers, 2013, 92, 1, 400-406

[10] Yasin, S., Behary, N., Giraud, S., Perwuelz, A., In situ degradation of organophosphorus flame retardant on cellulosic fabric using advanced oxidation process: A study on degradation and characterization, In: Polymer Degradation and Stability, 2016, 126, 1-8

[11] Khanh, V.T.H., Huong, N.T., Influence of crosslinking agent on the effectiveness of flame-retardant treatment for cotton fabric, In: Industrial Textila, 2019, 5, 413-420, http://doi.org/10.35530/IT.070.05.1610

[12] Mohsin, M., et al., Softener impact on environment friendly low and zero formaldehyde cross-linker performance for cotton, In: Industria Textila, 2014, 65, 3, 134-139

[13] Deruiter, J., Ethers and Thioethers, In: Principles of Drug Action, Spring, Ethers., 2005

[14] Sohail, Y., Parag, B., Nemeshwaree, B., Giorgio, R., Optimizing Organophosphorus Fire Resistant Finish for Cotton Fabric Using Box-Behnken Design, In: International Journal of Environmental Research, 2016, 10, 2, 313-320

[15] Latchubugata, C.S., Kondapaneni, R.V., Patluri, K.K., Virendra, U., Vedantam, S., Kinetics and optimization studies using Response Surface Methodology in biodiesel production using heterogeneous catalyst, In: Chemical Engineering Research and Design, 2018, 135, 129-139

[16] Dutka, M., Ditaranto, M., Løvås, T., Application of a central composite design for the study of NOx emission performance of a low NOx burner, In: Energies, 2015, 8, 5, 3606-3627

[17] ASTM, D 6413 Standard Test Method for Flame Resistance of Textiles (Vertical test), 2015

[18] ASTM, D 2863 Standard Test Method for Measuring the Minimum Oxygen Concentration to Support Candle-Like Combustion of Plastics (Oxygen Index), 1997

[19] BS EN ISO 13934-1:2013 Textiles - Tensile Properties Of Fabrics - Part 1: Determination of Maximum Force and Elongation at Maximum Force Using the Strip Method (ISO 13934-1:2013), 2013

[20] NF EN ISO 14184-1:2011 Textiles - determination of formaldehyde - Part 1: Free and hydrolyzed formaldehyde (water extraction method), 2011

[21] Pengpeng, Q., et al., Application of Box-Behnken design with response surface methodology for modeling and optimizing ultrasonic oxidation of arsenite with $\mathrm{H}_{2} \mathrm{O}_{2}$, In: Open Chemistry, 2014, 12, 2, 164-172

[22] Price, D., Horrocks, A., Combustion processes of textile fibres, In: Handbook of Fire Resistant Textiles, Elsevier, 2013, 3-25

[23] ISO E, 11612: 2008, Protective Clothing - Clothing to Protect Against Heat and Flame, BeuthVerlag GmbH, Berlin, 2008

\author{
Authors: \\ NGUYEN THI HUONG ${ }^{1,2}$, VU THI HONG KHANH ${ }^{1}$, NGUYEN PHAM DUY LINH ${ }^{1}$ \\ ${ }^{1}$ Hanoi University of Science and Technology, Dai Co Viet, no. 1, Hai Ba Trung, Hanoi, Vietnam \\ e-mail: nguyenhuonghict@gmail.com, linhnpd@gmail.com \\ ${ }^{2}$ Hanoi Industrial Textile Garment University, Le Chi, Gia Lam, Hanoi, Vietnam
}

\section{Corresponding author:}

Assoc. Prof. VU THI HONG KHANH

e-mail: khanh.vuthihong@hust.edu.vn 